Mojca Medvedšek

\title{
Pismo Slovencu: vpliv Tomaža Šalamuna na brazilskega pesnika Narlana Matosa
}

Ključne besede: Tomaž Šalamun, brazilska poezija, medbesedilnost, Narlan Matos, prevodi

DOI: 10.4312/ars.11.2.178-191

\section{Uvod}

Pričujoča študija bo predstavila vpliv, ki ga je imel slovenski pesnik Tomaž Šalamun (1941-2014) na poezijo brazilskega pesnika srednje generacije Narlana Matosa (1975): osvetlili bomo kontekst njunega srečanja in Šalamunov vstop v brazilski literarni svet ter orisali pesniško in prevajalsko izmenjavo obeh avtorjev, prvine literarnega stika med dvema poetikama ter možne medbesedilne interakcije, ki zrcalijo in ostajajo odtisnjene v poetiki brazilskega pesnika Matosa, zlasti v njegovi tretji zbirki Elegija novemu svetu in druge pesmi (Elegia ao novo mundo e outros poemas, 2012), v katero je uvrščena tudi pesem Pismo Slovencu, posvečena Tomažu Šalamunu.

V spominskih zapisih ter strokovnih in znanstvenih člankih, ki so izšli v letu po Šalamunovi smrti, se številni ameriški prevajalci in pesniki spominjajo Šalamunovega živega zanimanja za mlajše pesnike, ki so hranili njegovo domišljijo ter mu jo vračali s prevodi in posnemanjem njegovih del. V posebni številki Literature, ki je prav tako izšla kot hommage umrlemu pesniku, je ob tej priložnosti Christopher Merrill izpostavil po njegovem mnenju ironično dejstvo, da je Šalamun, pišoč v jeziku, ki ga govori dva milijona ljudi, več desetletij odločilno vplival na pisanje poezije na ameriškem kontinentu in na porajanje novih, mladih pesniških imen v ZDA (Merrill, 2015, 148-151).

Amerika je na Šalamuna odločilno vplivala vse življenje, tja se je vračal kot gostujoči profesor na univerze, bralne nastope in festivale ter umetniške rezidence; zanj je bilo prelomnega pomena njegovo prvo bivanje v Iowi, ko je leta 1970 prejel štipendijo v okviru mednarodnega pisateljskega programa. V intervjujih je pogosto pojasnjeval, da mu je ameriški kontinent odprl celice, in trdil, da so njegove pesmi zadihale šele, ko so bile prevedene v angleščino (Merrill, 2015, 148-151). S svojim pisanjem pa ni odločilno vplival le na generacijo severnoameriških pesnikov, prevodi njegovih pesmi $\mathrm{v}$ angleščino so bili mnogokrat odskočna deska tudi za prevajanje 
njegovih del v druge jezike in vir raziskovalne radovednosti za pesnike, ki so lahko njegovo poezijo spoznali zgolj zahvaljujoč njenim angleškim prevodom.

Ko je leta 1997 v Združenih državah izšel obsežen izbor Šalamunove poezije Štiri vprašanja melanholije (Four Questions of Melancoly), je tudi Metka Zupančič v recenziji tega obsežnega antologijskega izbora Šalamunovega dela, ki je nastal s pesnikovim sodelovanjem, zapisala, da je Šalamun eden najbolj prevajanih tujih pesnikov v Združenih državah, zlasti zaradi živega zanimanja, ki ga vzbuja pri mladih pesnikih. Opozorila je na poseben jezikovni labirint zbirke in na »kolosalno prizadevanje trinajstih prevajalcev«, ki so Šalamunovo »magmo« slovenskega jezika presadili v idiomatske strukture angleškega in si pri tem prizadevali zlasti za ameriške pesnike, ki ne govorijo tega težavnega jezika, poustvariti »besedne vibracije Šalamunove poezije, da bi bilo začutiti njihovo kompleksnost« (Zupančič, 1996, 89-90).

\section{Šalamunov prvi literarni stik z Brazilijo}

V tem kontekstu torej ni prav nič nenavadnega, da se je za Šalamuna na prelomu tisočletja začel zanimati tudi takrat mlad brazilski pesnik Narlan Matos, ki je naslovil pismo Šalamunu, kulturnemu atašeju v New Yorku, ter ga v njem prosil, naj mu pošlje nekaj angleških ali španskih prevodov pesmi, ki jih bo prevedel v brazilsko portugalščino. Šalamun ga je povezal s Centrom za slovensko književnost v Sloveniji, ki $\mathrm{mu}$ je Matos leta 2000 pomagal soorganizirati prvo predstavitev slovenske literature $\mathrm{v}$ Braziliji, kjer so se poleg Šalamuna predstavili tudi Svetlana Makarovič, Brane Mozetič, Andrej Blatnik in Evald Flisar; ali, natančneje rečeno, pomagal je organizirati tisti del obsežne turneje, ki je potekal v zvezni državi Bahia v mestu Salvador. V intervjuju za Delo je takrat povedal, da ga je na poezijo Tomaža Šalamuna opozoril pesnik in prevajalec Kerry Shawn Keys:

Prek njegovega dela sem prišel v stik tudi s Slovenijo. Šalamunova poezija je bila natanko to, kar sem iskal. Postal je moj resnični učitelj in izvir inspiracije. Zato sem se odločil, da pomagam pri izmenjavi obeh kultur, prevajanju slovenskih avtorjev in njihovih objavah v Braziliji. Zame ta bralna turneja ni zgolj obisk slovenskih pesnikov in pisateljev, temveč šele začetek velike kulturne izmenjave (Delo, 20. 4. 2000).

Intervju s takrat petindvajsetletnim pesnikom nadalje razkriva njegov odnos do literature in pisanja, iz katerega je mogoče tudi razbrati, zakaj je mladi pesnik vzbudil Šalamunovo zanimanje:

$\mathrm{V}$ resnici nimam vedno nadzora nad sabo, nad svojim življenjem. [...] Včasih se počutim in delujem, kot da sem $\mathrm{v}$ srednjem veku, v romantiki, v moderni dobi. Govorim z ljudmi, ki so umrli pred 100, 200, 300 leti, ponoči, v sanjah, 
v temi, z ljudmi, ki so vselej okoli mene, me strašijo in mi pomagajo. Moja literatura je poslušanje teh glasov (Delo, 20. 4. 2000).

Šalamun je ves čas zavestno deloval z željo, da bi pomagal oblikovati pesniške prostore, ki presegajo nacionalne okvire; na literarnih srečanjih so ga privlačili tisti mladi pesniki, v katerih je prepoznal njihovo občudovanje, sorodno zaznavanje sveta in možnost za pesniško intervencijo. ${ }^{1}$ Kot je zapisal sam, je želel sooblikovati »svetovno energijo « (Šalamun, 2011, 954). Iz pričevanj tistih pesniških sopotnikov, ki so občudovali Šalamunove neverjetne socialne sposobnosti, je mogoče izluščiti, da je bilo pri njem ves čas vidno živo zanimanje za fantazmatske mehanizme, ki poganjajo svet, in da:

[...] ni bil zgolj potopljen v socialno dimenzijo sveta, ampak se je kot pesnik onkraj nje vedno direktno soočal s fantazmatskimi okviri, na katere je pripeta družbena realnost, in z mehanizmi, ki to realnost poganjajo. Bil je svetel in blag, obenem pa se je ves čas gibal v sferi sanj in somraka (Komelj, 2015, 93).

Bralna turneja slovenskih avtorjev v Braziliji je poleg prevodov v portugalski jezik, zbranih v posebni izdaji Litterae slovenicae (publikacije Društva slovenskih pisateljev, 1999), dobila odmev v recenzijah v največjih brazilskih dnevnikih (Folha de São Paulo, Estado de São Paulo, o Globo) in objavah v literarnih revijah (Cult, Poesia+). To so bile obenem prve objavljene Šalamunove pesmi v brazilskem literarnem prostoru, in sicer v prevodih Narlana Matosa (Paris, 1978, Palavra, Eclipse I), Raula Ferreire (Cogumelos III) in Mojce Medvedšek (Cervo, Jônio, History, Aquedotto, Peixe). ${ }^{2}$

Čeprav so se po srečanju v Braziliji in prvem prevajalskem odtisu Šalamunove poezije njune geografske poti razšle, je slovenski pesnik v več pogledih bistveno zaznamoval Matosovo življenjsko in pesniško pot; Matos je celo zapisal, da je bil največji vpliv njegovega slovenskega učitelja $\mathrm{v}$ poeziji pravzaprav vsak življenjski nasvet, ki ga je dobil od njega (Matos, 2012, 10). Ne le, da je z njegovim posredovanjem spoznal ameriškega pesnika Roberta Hassa, ki mu je odprl nove pesniške horizonte, na Šalamunovo priporočilo se je leta 2002 vpisal v program kreativnega pisanja na Univerzi v Iowi kot štipendist programa International Visitors Leadership Program, kjer je bil njegov pesniški mentor nobelovec Derek Walcott. Študij je nato nadaljeval na Univerzi New Mexico v Združenih državah, na Univerzi Illinois pa je zagovarjal doktorsko disertacijo z naslovom Inventory of Chaos: Rogério Duarte, Tropicália and

1 Tudi Andrej Blatnik, pisatelj, ki je bil Šalamunov sopotnik na predstavitvi sodobne slovenske literature v Braziliji, se spominja na desetine pesnikov, ki so mu po vsakem nastopu nosili svoje knjige. Šalamun jih je zlagal v svoj kovček, in ko je bil prepoln, je odnašal pakete na pošto. Vedno se je čutil zavezanega, da zlasti knjige mladih pesnikov bere tako resno, kot so bile napisane. S posebnim užitkom je bral knjige mlajših, tistih, ki so po njegovem mnenju šele prihajali (Blatnik, 2015, 129).

2 Vse medijske in literarne objave so zbrane na povezavi: http://www.ljudmila.org/litcenter/brazil/ press/index2.html [15. 6. 2017]. 
Post-Modernity. Postal je specialist za postmodernizem v Braziliji in literarno gibanje Tropicalia. Vse od začetka poti, na katero je stopil s pomočjo svojega pesniškega očeta, se ni več za stalno vrnil v Brazilijo. Od leta 2004 živi in ustvarja v ZDA in brazilsko književnost predava na Montgomery Collegeu v Washingtonu (Matos, 2012, 9).

\section{Splošna opredelitev poetike Narlana Matosa}

Matosovo prvo pesniško zbirko Dame in gospodje: dani se! (Senhoras e senhores: o amanhecer), ki jo je objavil pri 21 letih in zanjo leta 1997 prejel literarno nagrado Braskem, ki jo podeljuje fundacija Casa Jorge Amado, so pozdravili številni uveljavljeni brazilski pisateljski glasovi, med drugim Ferreira Gullar (1930-2016) in Herberto Sales (1917-1999). Matos je v uvodu v tretjo pesniško zbirko, Elegijo novemu svetu, zapisal, da še vedno hrani list papirja, na katerega je Šalamun, ko je prebral njegovo prvo delo, zapisal: »tvoja poezija me žge« (Matos, 2012, 9). Tudi za drugo knjigo poezije $V$ taboru senc (No Acampamento das Sombras, 2001) je Matos osvojil nacionalno brazilsko nagrado za poezijo (Xerox Award) na največjem univerzitetnem festivalu literature $\mathrm{v}$ Bahiji.

Gre za zbirki mladostnega zamaha, ki v pesmih razkrivata sublimnega prebivalca sveta, povezanega tako $\mathrm{z}$ intimnimi, malimi stvarmi in dogodki vsakdanjega življenja kot $\mathrm{z}$ oblaki in premikanjem nedotakljivega, neotipljivega. Jorge de Souza Araujo je v zapisu, ki je pospremil izid prve zbirke, izpostavil, da se pesniški jezik v Dame in gospodje: dani se! "preliva skozi izsušena usta in skuša odgovarjati na osnovna vprašanja o smrti poezije, splavu senc in zlohotnem vsakdanjiku, ki je tako temačen, da v njem ne zmoremo ločiti svetlobe dneva od teme, uzreti luči porajajočega se dneva« ${ }^{3}$ Matos, v prvih dveh zbirkah naslednik rimbaudovske tradicije, v njej na jezikovni ravni pogosto kombinira pomensko oddaljene besede ter s tem ustvarja lasten kozmos jezika in domišljije, ki je intoniran z izrazito temačnim občutjem.

Matosovo pesniško govorico je v tretji zbirki, Elegija novemu svetu in druge pesmi ${ }^{4}$ (Elegia ao novo mundo e outros poemas, 2012), leta 2004 povsem prenovilo njegovo bivanje v Združenih državah v državi Nova Mehika (Albuquerque), kjer je študiral, in ki mu je razkrilo neko drugo Ameriko. Amerika se mu nenadoma pokaže kot preplet različnih narodov in etnij - mehiške (čikanske) kulture, indijanske kulture (Navajo), karibske Amerike, Amerike emigrantov. Pesnik je v tej zbirki sicer še vedno zvezan z latinskoameriško modernistično tradicijo in tradicijo tropikalizma, a ji doda še vedno živo tradicijo beatniške poezije, ki je navdihovala tudi mladega Šalamuna (Matos, 2012, 9). Njegovo bivanje v mestu Albuquerque poeziji daje nov naboj, ki je svetlejših

3 http://www.narlanmatos.com/poesia.html [10. 6. 2017].

4 Avtorica zbirko od tu dalje imenuje Elegija. 
tonov in bolj odprt ter prinese vpliv idejnega prepiha, ki je poleg medbesedilnih reakcij na poezijo Creeleyja in Ferlinghettija posledica pesnikovih potovanj, obenem pa jo prežema zavedanje in preizpraševanje lastne, kompleksne identitete, zlite iz portugalskih, indijanskih in črnskih korenin (Matos, 2012, 10).

Povezanost Matosove poetike s Šalamunovo poezijo se najmočneje (in kronološko logično) kaže v Elegiji. Na tem mestu naj vzpostavimo prvo očitno povezavo med fascinacijo brazilskega pesnika nad geografskimi pojavi, zgodovino in intimnim spominom na celoten kontinent Amerike ter dinamiko časa in gibanja, ki zaznamujeta Šalamunov modernizem. Šalamun je kar naprej potoval; smeri in sledi njegovih potovanj poznamo iz njegovega pesniškega "potopisa«: Amerika, Hvar, Mehika, St. Nazaire, Amerika, Berlin, spet in spet Amerika. Nov, soroden kozmopolitizem zaveje tudi iz Matosove Elegije; tudi zanj je Amerika obljubljena dežela, čeprav ni zgolj popotniška destinacija: je tudi dežela njegove intelektualne in literarne realizacije, dežela, kjer biva (Novak, 2005, 259).

Ameriška kultura je, verjetno zaradi prostorskih razsežnosti, potovanje povzdignila na raven kulta; kategoričnemu imperativu potovanja, premikanja, tej temeljni paradigmi hipijevske generacije, se Matos ne izogne; ob robu legendarne Route $66 \mathrm{v}$ nekem motelu izve za smrt Roberta Creeleyja (Matos, 2012, 10), in kar je še očitneje: v kazalo Elegije se kot rezultat potovanj vtisne katalog naslovov namišljenih in realnih geografskih krajev Južne, Srednje in Severne Amerike (Latinamerica, Tenochtitlan, Republica Dominicana, Mesečina v Havani, Wall street, Zapuščena plaža v Kaliforniji, Australna Amerika itd.), ${ }^{5}$ ki jim Matos ne glede na to, ali po njih potuje ali ne, izpiše svojevrstne epske portrete (Matos, 2012, 7-9).

Takšen način zrcaljenja $\mathrm{v}$ poetikah je mogoče pogledati skozi optiko medbesedilnosti; ta tekst razume kot odprto tvorbo, ki vsebuje sledi celovite družbene resničnosti z njenimi diskurzi vred, kot semiotično strukturo, ki je z verbalnim tekstom v nenehni interakciji (Juvan, 2000, 255).

\section{Pismo Slovencu v Elegiii}

Šalamun sodi med tiste avtorje, ki v literaturo nenehno vpletajo elemente zunajbesedilnega sveta s citati, aluzijami in referencami ter predvidevajo, da bodo njihovi bralci dovolj razgledani, da jih bodo prepoznali. Čim bolj je bralec informiran, bolj seznanjen s književnim delom, tem laže prepozna citate, jih razume in vključi v razumevanje besedila. Tako avtorjev postopek kot bralčev način sprejemanja izvirata

5 Pesmi so objavljene tudi v slovenščino prevedeni zbirki Pesmi o vetru in mojem življenju (Matos, 2015). 
iz temeljne človekove potrebe po posnemanju in ponavljanju, ki je bilo že od nekdaj nujno za ohranjanje védenja tako za lastno preživetje kot za izročilo potomcem (Juvan, 2000, 245-247). Zaradi njegove vplivnosti in povezanosti $\mathrm{z}$ več generacijami pesnikov in prevajalcev ter privlačnosti njegove jezikovne alkimije je spričo intrigantnih, včasih izmuzljivih ter obenem sproščenih in odprtih pesniških strategij njegov vpliv mogoče opazovati v posnemanju njegovih pesniških postopkov. ${ }^{6}$

Šalamunove predstavitve v poeziji drugih pesnikov so izjemno heterogene iz več razlogov: zaradi njegovih bogatih stilno-retoričnih in semantičnih strategij, umetnostnih ter kulturnih zaznamkov in referenc, njegove svetovnonazorske drže in političnih stališč (Novak-Popov, 2015, 216). Zanimanje, ki ga v prispevku posvečamo odmevu Šalamunovega dela pri Matosu, velja medbesedilnim interakcijam, ki se bodisi eksplicitno (s citati, nagovori) bodisi implicitno (aluzija, reminiscenca, pastiš) sklicujejo na predhodnikove tekstualne ali strukturne dosežke ter na tem ozadju začrtajo novo pesniško krajino (ibid.). Zrcaljenje pesnika skozi nove interpretacije kaže, kaj ostaja za določen čas relevantno, kaj se lahko (tudi spričo prevoda, oziroma posrednega jezika) ohranja in kaj spreminja. Izhodišče za opazovanje pesniških besedil je pojmovanje medbesedilnosti ${ }^{7}$ kot dejavnika literarnega razvoja, ki naj bi »s svojo dialoškostjo, proizvajanjem razlik in odklonov spodbujala spremembe in poganjala literarne procese« (Juvan, 2000, 208).

V Matosovi pesmi Pismo Slovencu, ki je izšla v zbirki Elegija, tako lahko izpostavimo povezanost s Šalamunovo poezijo v nekaj ključnih točkah: v asociativnih preskokih in ludizmu ter v iskanju in posnemanju tipičnih ritmičnih vzorcev Šalamunovega verza in njegove glasbenosti.

Naj na prvem mestu izpostavimo tehniko asociativnih preskokov, ki jo Matos kot referenco uporablja v dialogu z učiteljem. Preskoki ustvarjajo nepredvidljivo, nadrealistično besedilno logiko, ki se pogosto konča v nonsensu. Šalamun je svoj jezik

6 Iz intervjuja Mete Kušar razberemo, da je Šalamun pozorno spremljal besedila o svojem delu; izjavil je, da je »bilo napisanih šestdeset, sedemdeset [njemu posvečenih] pesmi«v sedmih jezikih; kot motiv za njihov nastanek navaja prijateljstvo, zaljubljenost ali njegovo poezijo (Kušar, 2009, 164).

7 Termin intertekstualnost v svojem kontekstu definira tudi Gérard Genette v delu Palimpsestes (1982); izraz v uvodu v okviru lastnega pojmovanja transtekstualnosti najprej pojasni kot »vse, kar neko besedilo postavlja v odnos, bodisi na nedvoumen ali pa skriven način, z nekim drugim besedilom « (Genette, 1982, 7), v uvodu pa ponovno definira pojme intertekstualnosti, paratekstualnosti, metatekstualnosti, arhitekstualnosti in hipertekstualnosti (ibid., 8-14). Enega od tipov transtekstualnosti tako pojmuje kot hipertekstualnost in pojasni: »S tem razumem kakršenkoli odnos, ki združuje besedilo B (kar bom imenoval hipertekst) s predhodnim tekstom A (ki ga bom imenoval hipotekst) in se nanj pripenja na način, ki ni komentar« (ibid., 12). Genette govori o besedilu druge ravni (»second degré«) ali o besedilu, ki je izpeljano iz predobstoječega besedila. Izpeljava novega besedila je lahko deskriptivno ali intelektualno besedilo, lahko tudi metabesedilo ali pa popolnoma druge vrste besedilo; takšno, pri katerem besedilo A ne navaja besedila B, vendar brez njega ne bi moglo obstajati, nastane pa s pomočjo operacije, ki jo Genette provizorično imenuje »transformacija« (ibid., 13). 
očistil sentimentalizma, da bi izrazil resnico sveta. Podlaga za ta njegov postopek je kombinatorika pomensko oddaljenih besed, ki ustvarjajo nov svet jezika in poetične domišljije (Novak, 1996, 87). Iz te brezmejne svobode ravnanja z jezikom izhaja gibanje, ki ga je Taras Kermauner imenoval ludizem $^{8}$ in se v Elegiji bere: „Pišem / ker je danes ponedeljek / in jo bom jutri spet srečal / [...] in ker si želim obiskati tudi Bolivijo in Venezuelo / in ker Indijancem na ameriškem kontinentu grozi izumrtje« (Matos, 2015, 62).

Ludistični postopek, ki ga Matos v svojem delu označuje kot absurd, ima svoj pendant $\mathrm{v}$ tem, kar Kermauner imenuje načelo paradoksalike. To pomeni, da so verzi s samimi sabo v paradoksalnem nasprotju: »Paradoksalika se podaja drugačni naravi: samo sebe in svet spodbija; z namenom, da bi se spodnesla. Nič iz nje ne zraste; niti kapelica. Nič ne nastane, kar že ni bilo; česar ne bi prejšnji svet napravil« (Kermauner, 1991, 324). Juvan kasneje opozarja, da je Šalamunov Poker nastal, še preden je Kermauner vpeljal izraz, s katerim je označil literarni tok, v katerem je igra glavno estetsko vodilo (Juvan, 2000, 281).

V primeru Matosove pesmi Pismo Slovencu (Matos, 2015, 75) se ludizem kaže v pesnikovih ponavljajočih se miselnih preskokih: »odkar sem se rodil na neki čisto navaden ponedeljek, / me je navadno življenje zasledovalo vsepovsod «, in spet na drugem mestu: »kmalu bo začela vame padati jesen, vem, / moji listi bodo odpadli«. Kot v katalogu potez ludističnega pejsaža Šalamunovega Pokra, navaja Juvan, gre za princip kršenja in sprevračanja načel logičnosti in kavzalnosti kodov, »ki blokirajo svobodno označevanje $\mathrm{s}$ teleologijo smisla in $\mathrm{v}$ besedilo vnašajo koherentnost, neprotislovnost, ujemanje $\mathrm{z}$ intersubjektivno preverljivo resnico « (Juvan, 2000, 286). Šalamun racionalnost s preigravanjem logike privede do absurda $\mathrm{z}$ izmišljanjem vrste absurdnih utemeljitev: »odstranili bomo dihanje / ker se udira«, »odstranili bomo nebo / in vodo ker se začne na V «(Šalamun, 2011, 24).

Matos povzema še eno lastnost Šalamunovega ludizma, to, kar Juvan imenuje piščevo izigravanje bralčevega pričakovanja; pričakovanje, da bo lirski govor imel globino, pomen in da bo mišljen kot pristna izpoved. Tudi pri Matosu se kitica začne, kot da gre za vsakdanjo pogovorno situacijo: »in kot tako življenje obstaja« - s svojevrstno ležernostjo, ki ne ustreza predstavam o liriki in pesniškem izrekanju ${ }^{9}$ (Juvan, 2000, 286). Namesto z usodnim življenjskim spoznanjem pesnik v izpeljavi

8 »Ludizem je literarna ideologija igre. Šalamun jo je prvi in najbolj pristno vnesel na Slovensko. V mnogočem ji je ves čas pokoren. Obenem pa je že od začetka Šalamunovo pisanje poezija, kar pomeni, da biva, mnogo močnejše, neodvisna, poleg ideologije. [...] Šalamunova poezija daleč presega ludizem. Skozi obstoj in pomen maske sega v okrožje bitnega in svetega. Se je pesnik približal alogiki barbarstva, podivjanemu kaosu, ki nas v sistemu koda tako privlači, najbolj očaruje, čeprav je navidezen, prevara? (Kermauner, 1991, 324). 
verza zaključi s poljubnim, privatnim, neresnim spoznanjem: $:^{10}$ "pa kaj (Matos, $2015,75)$.

Matos pesem na več mestih gradi tudi s pomočjo preprostih, mestoma otroških vprašanj, ki aludirajo na Šalamunovega Jona,${ }^{11}$ a v nasprotju z njim nimajo iracionalnih odgovorov in ostajajo neodgovorjena: »kaj storiti / kam oditi? / koga poiskati? « ali pa »in kaj naj storim z melanholijo? / in kaj naj storim z vrtom rumenih rož?«

V pesmi zasledimo tudi citat, povezan s Šalamunovo izjavo o Matosovi poeziji. V nekem pismu Šalamun Matosu napiše, da ga »njegova poezija žge« (Matos, 2015, 9). Tako v izteku pesmi beremo: "slišim kri v venah, v agoniji / in kitaro v prsih ki me žge" (Matos, 2015, 76). Tudi kri je element, ki se v Šalamunovi poeziji pogosto pojavlja, pogosto kot sinonim za živost, življenjskost, neke vrste ritualno prenovo: »Moč ne sme izhlapevati. [...] / Ljudje ki gazimo po krvi smo / erotični in zanimivi« (Šalamun, 2011, 651).

Šalamunova zapisanost premikanju, dinamičnosti in potovanjem, o kateri smo govorili uvodoma, odmeva v prvi kitici Matosove pesmi; potovanje, premikanje po zemljevidu Matos sprejme, a ga obenem zmede - pri njem v nasprotju s Šalamunovim optimizmom, navdušenostjo in svetlobo prepotovanih krajev potovanje zveni $\mathrm{z}$ brezciljnostjo in preizprašuje smisel potovalnega imperativa: »hodim po obali južnega Atlantika / brez začrtane poti / brez zemljevida / sol morja je vse kar čutim v zraku in na ustnicah / kakšen zaklad so tropi pustili zame? « (Matos, 2015, 76).

Ob analizi pesmi opazimo, da Matos ob branju Šalamunove poezije zapiše tudi odziv, ki je kot uvid ali posledica zaupnega pesniškega dialoga s slovenskim kolegom, in pesem zaključi v končno koncentrirano spoznanje: »Tomaž Šalamun / bil sem obsojen na obstoj.« Obsojenost na pesniški obstoj je obenem Matosova vdaja v pesniško usodo v tej pesmi in odziv na Šalamunovo imperativno odločenost v pesmi Vzgoja, s katero si želi zaznamovati in prežeti vso literaturo: »Jaz sem večen gejzir. / Vzgajam jih, da me bodo pisali« (Šalamun, 2011, 489).

Čeprav pri analizah Šalamuna literarni zgodovinarji radi trdijo, da je pesnik zapisan dekonstrukciji tradicionalnih pesniških oblik, Novak v svojem premisleku o ritmu v Šalamunovi pesniški govorici ugotavlja, da njegova izrazna moč izvira iz napetega, dramatičnega ritma pesmi in da veliko njegovih verzov temelji na spoštovanju klasičnih metričnih shem. Ugotavlja tudi, da so pri njem še pogostejši verzi, pri katerih je mogoče izluščiti metrično osnovo, a jo pesnik nadgrajuje z živim

10 Pri Šalamunu: »najboljše so gobice / gobice v juhi« (ibid.).

11 Gre za eno najbolj prevajanih pesmi, ki jo je v portugalščino prevedel tudi Matos: »kako zahaja sonce? / [...] kakšne barve je morje? / [...] jon si slan?« (Šalamun, 2011, 114). 
utripom besedne materije; zato Novak namesto tradicionalnega termina metrična shema uporablja ustreznejši izraz metrični impulz (Novak, 1996, 88).

Matos v analizirani pesmi - da bi dosegel tudi želeni formalni dialog - vztrajno uporablja anaforo, retorično figuro, ki temelji na ponavljanju začetnih besed stavkov ali verzov (v pesmi Pismo Slovencu so to predlogi ali vezniki): »Tomaž Šalamun, / in kaj naj storim $\mathrm{z}$ melanholijo, / in kaj naj storim $\mathrm{z}$ vrtom rumenih rož? « V navedenem primeru navaden veznik pridobi nenavadno, nevsakdanjo težo. Takšnih mest je v Elegiji še nekaj; v pesmi Mesečina Havane na primer: »ko smo se vozili nad Karibi / je bila noč / je bila globoka noč / je bila spet noč «12 (Matos, 2015, 68). Ponavljanje besed in sintagem (npr. »Tomaž Šalamun« v Pismu Slovencu), ki se kot refren ponavlja v vsakem prvem verzu kitic, je eden poglavitnih ritmično pomenskih postopkov Šalamunove poetike, pri kateri pridane inverzije $\mathrm{v}$ sintaksi in močne podobe prispevajo $\mathrm{k}$ strašnejšemu, preroškemu učinku pesmi. V zvezi z glasbenostjo Šalamunove poezije ni mogoče spregledati Novakove opombe, da se je naravnanost k zvočnemu učinkovanju pesmi v toku njegovega pesniškega razvoja le še krepila. Ponavljajoči se verzi, ki ritemsko učinkujejo kot refren (zelo izrazito na primer že v zbirki Poker), kažejo na Šalamunovo tendenco, da je pesmi organiziral v skladbo, kot glasbo, kar je gotovo mogoče povezati z dejstvom, da je bil kot mladenič zelo talentiran pianist in je dobro poznal tako klasično glasbo kot njene popularne oblike (Novak, 1996, 94). Enako velja za Matosovo zbirko Elegija. Glasbenost pesmi je prvina brazilske pesniške tradicije, pesmi se zapisujejo, da bi bile izgovarjane ali celo zapete, zato Matosu naravnanost k zvočnemu učinkovanju pesniške besede ni tuja in je prisotna v vseh treh pesniških zbirkah; je kot odmev zavezanosti brazilski popularni glasbi in gibanju Tropicalia. Glasbi se je posvečal ne le v teoretičnem smislu, ampak jo je vključeval tudi v svoja branja na nastopih, na katerih je poleg poezije predstavljal tudi lastno glasbo, ki jo je imenoval bossa negra. ${ }^{13}$

\section{Sklep}

Med Šalamunovimi predlogami in navezavami v delu Narlana Matosa je precejšnja časovna razdalja. Matos se sklicuje zlasti na dela, ki jih pozna prek španskih in angleških prevodov in ki jih je na začetku svoje pesniške poti prevajal tudi sam; v veliki večini so to pesmi iz zgodnjega Šalamunovega opusa, torej zbirk iz 70. ali 80. let, kakor da bi njegovega pesniškega učenca zanimala predvsem mladost. Kot je značilno za njegove številne nadaljevalce, je tudi za Matosa poezija posebna vrsta

12 Šalamun v pesmi Kaj je kaj: »to je čedno / to je izredno čedno / to je tako čedno« (Šalamun, 2011, 86).

http://www.narlanmatos.com/music.html [10. 6. 2017]. 
poklicanosti in osebnega angažmaja (v Matosovem primeru se avtor osredotoča na vprašanja kolonializma, identitete, rasizma in ameriškega kontinenta). Sklicevanje na Šalamuna se pri Matosu pojavi šele v tretji pesniški zbirki in se udejanji zlasti v pesmi Pismo Slovencu. Dialog s Šalamunovo poezijo poteka v nekaj ključnih točkah: $\mathrm{v}$ asociativnih preskokih in ludizmu ter $\mathrm{v}$ iskanju in posnemanju tipičnih ritmičnih vzorcev Šalamunovega verza in njegove glasbenosti. Matos Šalamunove pesniške predloge uporabi igrivo, odprto in svobodno, s spoštljivostjo, a brez kritične distance ali ironije. Ob ponavljanju Šalamunovega imena kot svojevrstnega imperativa v izbrani pesmi Pismo Slovencu, ki je vidna in vseprisotna pesnikova referenca, pa Matos s posnemanjem nekaterih stilemov po svoje ureja besedilo in jih vključuje vanj, ne da bi jih eksplicitno označeval, kar lahko mestoma, v kontekstu medbesedilnosti, imenujemo tudi pastiš (Juvan, 2000, 45). V Matosovi poetiki je v posnemanju, aludiranju in dialogu s Šalamunovim pesniškim izrazom mogoče prepoznati izraz postmodernega, literaturo, ki nastaja iz literature in ki stavi tudi na mobilnost, interkulturnost in enciklopedičnost. Matosova poezija je najmočnejša na mestih, kjer zmore bivanjsko izkušnjo in realne okoliščine precizno in izvirno izraziti v dialogu s slovenskim avtorjem, s čimer ustvarja nove poti, poti, ki si jih tudi veliki učitelj ni mogel zamisliti.

Matos je v Slovenijo, da bi ponovno srečal svojega učitelja, pripotoval po njegovi smrti, novembra 2015, ko je izšel prevod njegove poezije v slovenski jezik, izbor pesmi treh zbirk v prevodu Blažke Müller Pograjc in Mojce Medvedšek. Slovenska izdaja nosi posvetilo: »Tomažu Šalamunu, prijatelju, bratu, očetu, sinu.«

Šalamun se je v Brazilijo po letu 2000 vrnil še večkrat: na branja, ki jih je organiziralo slovensko veleposlaništvo v Braziliji, in nazadnje, leta 2013, na enega največjih umetniških festivalov Artes Vertentes v mestu Tiradentes (zvezna država Minas Gerais). Na festival je prišel na povabilo organizatorjev Luiza Gustava Carvalha in Ricarda Domenecka, predstavnikov nove generacije pesnikov in prevajalcev, ki ju je njegova poezija navdušila in sta vanjo prav tako vstopila prek prevajanja $\mathrm{z}$ namero, da bi začela ustvarjati Šalamunovo brazilsko antologijo. ${ }^{14}$

Blatnik je po Šalamunovi smrti zapisal:

Tomaž Šalamun je znal vedno znova prestopati meje, ki jih je začutil s prihodom nove generacije. Je nekakšen simbolni oče vsem novim pesnikom, ki imajo ambicijo, da bi bili pesniki tudi znotrajbesedilno. [...] Vsaka nova generacija se mora do Šalamuna opredeliti, tako ali drugače. Vsaka nova generacija mora na novo odkriti in zakriti Šalamuna (Blatnik, 2015, 128).

14 http://revistamododeusar.blogspot.hr/2013/08/tomaz-salamun.html [5. 6. 2017]. 


\section{Bibliografija}

\section{Viri}

Antologia Poetica, Poesia Brasileira, Salvador 2006.

Matos, N., Senhoras e senhores: o amanhecer!, Salvador 1997.

Matos, N., No acampamento das sombras, Salvador 2001.

Matos, N., Elegia ao novo mundo e outros poemas, Rio de Janeiro 2012.

Matos, N., Pesmi o vetru in mojem življenju, Ljubljana 2015.

Nove Poetas Eslovenos Contemporâneos, Ljubljana 2000.

Quatro Escritores Eslovenos, Ljubljana 2000.

Šalamun, T., The four questions of Melancholy, Buffalo, New York 1997.

Šalamun, T., Poker, Ljubljana 1966.

Šalamun, T., Amerika, Ljubljana 1972.

Šalamun, T., Arena, Ljubljana 1973.

Šalamun, T., Metoda angela, Ljubljana 1978.

Šalamun, T., Balada za Metko Kraševec, Ljubljana 1981.

Šalamun, T., Glagoli sonca. Izbrane pesmi, Ljubljana 1993.

Šalamun, T., Kdaj. Izbrane pesmi, Ljubljana 2011.

Treze Poetas Eslovenos, Lizbona 2008.

Spletni viri

http://revistamododeusar.blogspot.hr/2013/08/tomaz-salamun.html [5. 6. 2017].

http://www.ljudmila.org/litcent/brazil/press/index2.html [1. 6. 2017].

http://www.narlanmatos.com/index.html [10. 6. 2017].

Literatura

Beckman, J., Predgovor prevajalca, v: Tomaž Šalamun, Kdaj, Ljubljana 2011, str. 966970.

Blatnik, A., Odpiranje vrat, Literatura 285, 2015, str. 126-130.

Brejc, T., Tomaž Šalamun in Julian Schnabel, v: Šalamun, T., Poker, Ljubljana 1989, str. 7-21.

Genette, G., Palimpsestes, Pariz 1982.

Juvan, M., Intertekstualnost, Ljubljana 2000 (Literarni leksikon, 45).

Juvan, M., Vezi besedila, Ljubljana 2000. 
Kermauner, T., Poezija slovenskega zahoda, 2. del, Maribor 1991.

Komelj, M., Govor na pogrebu Tomaža Šalamuna, Literatura 285, 2015, str. 89-99.

Merrill, Ch., Spomin na Tomaža Šalamuna, Literatura 285, 2015, str. 148-151.

Novak, B. A., Ritem pri Šalamunu, Literatura 65/66, 1996, str. 86-96.

Novak, B. A., Poetika forme, Ljubljana 1997.

Novak, B. A., Zven in pomen, Ljubljana 2005.

Novak-Popov, I., Novi sprehodi po slovenski poeziji, Ljubljana 2014.

Šalamun, T., Ta prostor bo preživel samo s strahotnim naporom vseh nas, v: Meta Kušar, Intervju, Ljubljana 2009, str. 161-172.

Zupančič, M., The Four Questions of Melancholy, Slovene Studies Journal 1, 1996, str. 89-95. 
Mojca Medvedšek

\section{Pismo Slovencu: vpliv Tomaža Šalamuna na brazilskega pesnika Narlana Matosa}

Ključne besede: Tomaž Šalamun, brazilska poezija, medbesedilnost, Narlan Matos, prevodi

Članek bo predstavil vpliv, ki ga je imel slovenski pesnik Tomaž Šalamun (19412014, Slovenija) na poezijo brazilskega pesnika srednje generacije Narlana Matosa (1975, Itaquara, Bahia): osvetlil bo kontekst njunega srečanja in Šalamunov prvi vstop $\mathrm{v}$ brazilski literarni svet ter orisal prevajalsko in pesniško izmenjavo obeh avtorjev, prvine literarnega stika med dvema poetikama ter medbesedilne interakcije, ki se zrcalijo v poetiki brazilskega pesnika Matosa, zlasti v njegovi tretji zbirki Elegija novemu svetu in druge pesmi (Elegia ao novo mundo e outros poemas, 2012), v kateri se sklicevanje na Šalamuna udejanji zlasti v pesmi Pismo Slovencu. Matosov dialog s Šalamunovo poezijo poteka v nekaj ključnih točkah: v asociativnih preskokih in ludizmu ter v iskanju in posnemanju tipičnih ritmičnih vzorcev Šalamunovega verza in njegove glasbenosti. 


\section{Mojca Medvedšek}

\section{Letter to a Slovenian: the influence of Tomaž Šalamun on Brazilian poet Narlan Matos}

Keywords: Tomaž Šalamun, Brazilian poetry, intertextuality, Narlan Matos, translations

This article will present the influence of the Slovenian poet Tomaž Šalamun (19412014, Slovenia) on the poetry of the mid-generation poet from Brazil, Narlan Matos (1975, Itaquara, Bahia), and will highlight the context of their meeting and Šalamun's first entry into the Brazilian literary world. It will also outline the translation and poetic exchanges of both authors, and the elements of literary contact between two poetics and the intertextual interactions mirrored in the poetry of the Brazilian poet Matos, especially in his third collection entitled Elegy to the New World and Other Poems (Elegia ao novo mundo e outros poemas, 2012), in which the reference to Salamun is especially accomplished in the song Letter to a Slovenian. Matos's dialogue with Šalamun's poetry takes place in several key points: in associative leaps and playfulness, as in the search for and imitation of the typical rhythmical patterns of Šalamun's verse, along with his musicality. 